\title{
Obstacles Level of Learning Javanese Speech: A Phenomenology Study in Elementary School
}

\author{
Siti Wahyuni, S. Subiyantoro, \& S. S. Fadhilah \\ Universitas Sebelas Maret \\ Solo, Indonesia \\ wah_yuni1748@yahoo.com
}

\begin{abstract}
This research explored the obstacles in learning Javanese speech acts. It was conducted in elementary school in Sragen. It used a qualitative approach. Data collection techniques used are observation, interviews with teachers and learners and documents analysis. Data validity is triangulation and data analysis techniques are Miles and Huberman's interactive model. The result of the research confirms that the learning barrier of Javanese speech level is the lack of comprehension of pronunciation, the concept of variety ngoko and karma and the low motivation of learners to learn Javanese languages both intrinsic and extrinsic one. Teachers always apply lecture methods in the learning and $95 \%$ teacher also do not come from Javanese background of education. In overcoming the obstacles in learning the level of Javanese speech, it requires learning innovation with the use of appropriate learning model, the use of Javanese language spoken well, improving learning facilities and teaching materials used and improving teachers' competence.
\end{abstract}

Keywords-obstacles level, speech java, language learning

\section{INTRODUCTION}

Javanese speech learning needs serious attention. The test result of ability to use Java language level speech towards 131 fifth graders in Sragen was 131 students got an average score of 41.73. Students who reach criteria of minimal value only $16 \%$ while as many as $84 \%$ didn't reach the minimum value of mastery. Graphic representation is as follows:

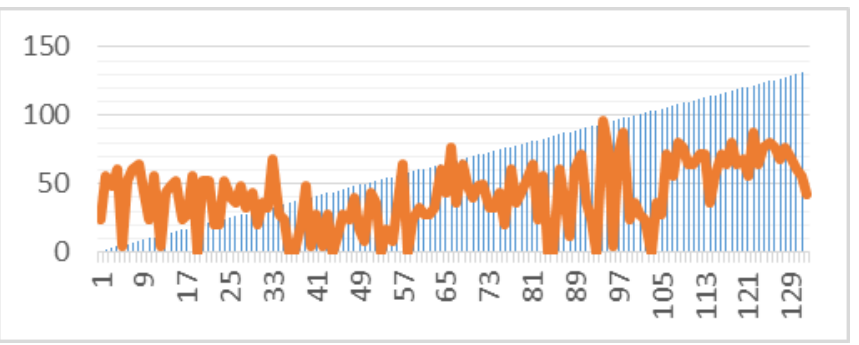

Fig. 1. The distribution of level speech Javanese language test scores

Teachers as the main implementers in learning should be able to design learning that is able to realize the educational goals that have been set [1]. [2] explains that teachers as reformers in the classroom must apply to students the culture of learning, such as learning to know, learning to do, learning to be, and learning to live together. Javanese language as one of the local content in Central Java which is used as the key to growing the character/affective of learners. This is in line with research from [3] that level of speech Javanese can be the key to the cultivation of the character ramah, sabar, tepa slira, hormat, empan papan, nuju prana, and subasita. However, in its implementation, there are some obstacles so that lessons are less meaningful, passive and not applicative. By applying Javanese level of speech, students will have a habit of being polite with friends or older people in the vicinity. Example of a child's conversation with teachers below:

\begin{tabular}{|c|c|c|}
\hline Student & : & Sugeng enjang Pak Guru \\
\hline Teacher & : & $\begin{array}{l}\text { Sugeng enjang, kowe kena ngapa yahmene } \\
\text { lagi mlebu kelas? }\end{array}$ \\
\hline Student & : & $\begin{array}{l}\text { Nyuwun pangapunten Pak, kula telat amargi } \\
\text { wau ban sepedha kula bocor, dados kula } \\
\text { tuntun dumugi sekolah. }\end{array}$ \\
\hline Teacher & : & $\begin{array}{l}\text { Apa bane ora kok deloki dhisik sadurunge } \\
\text { mangkat sekolah, bocor apa ora? }\end{array}$ \\
\hline Student & & $\begin{array}{l}\text { Sampun Pak, ananging niki wau kenging } \\
\text { paku dadose bocor. }\end{array}$ \\
\hline & & Yawis ora apa-apa, kana lungguh! \\
\hline & & Maturnuwun $I$ \\
\hline
\end{tabular}

From one of the examples of the above conversation shows how a student speaks politely using krama language and teacher speaks using the language of the variety of ngoko. Student speaks smoothly and politely towards an older person.

The level of speech in Javanese has the same word with undha usuk. It is divided into four categories namely ngoko lugu, ngoko alus, krama lugu and krama alus [4]. Javanese varieties of krama teach how to talk to the surrounding Javanese community as an effort to honor the elderly or knew someone. $[5,6]$ stated that the Javanese variety of krama isn't the mother tongue but as the second language for the children of Javanese speakers.

This study is relevant to some previous studies. First, The use of krama inggil (Javanese language) in the family domain at Semarang and Pekalongan cities by [5]. Second, a sociolinguistics study on the use of the Javanese language in the learning process in primary schools in Surakarta, Central Java, Indonesia by [7]. In addition to the above research, there is a study with the title Javanese level of speech is Motivations for first and second person subject expression and ellipsis in Javanese conversation by [8]. Furthermore, the research conducted by [9] on the relationship between speech mastery and extrovert attitude with speaking krama alus among student of Javanese language and literature education program of Semarang State University. 
It is known that this current research is different from previous researchers that lie the subject of research, research location, research methods used and emphasize the learning obstacles of Javanese speech acts in the elementary school. Based on the above background, this study aims to explore obstacles in learning Java language with the study of speech level.

\section{METHOD}

This research was conducted in Elementary School in Sragen for 5 months starting from February 2017 until June 2017. This study used a qualitative approach. Qualitative research is conducted through a process that departs from the general to the general, the conceptualization, categorization, and the description of the problem under investigation [10]. The type of research used is phenomenology study. The data analysis is interactive analysis according to [11] covering the first stage is the stage of data collection, the second stage is the data reduction phase, the third stage is the data display stage and the fourth stage is the conclusion phase. The research procedure performed is as follows:

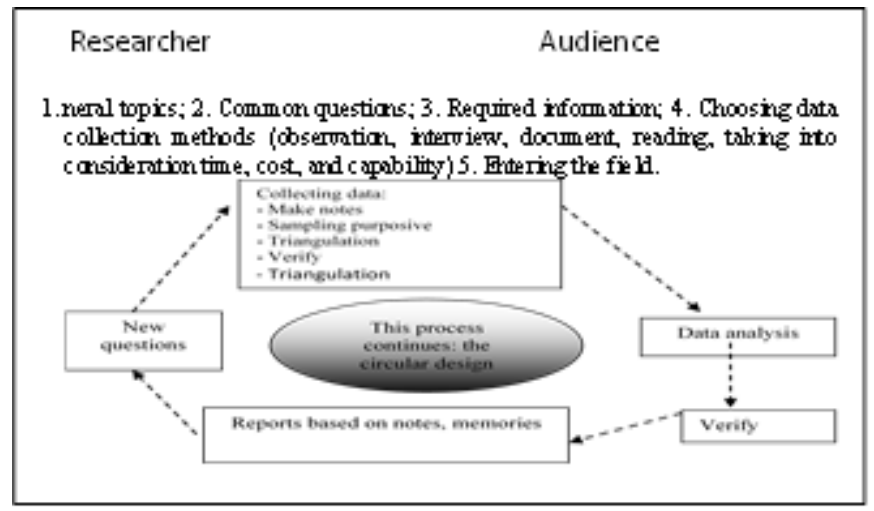

Fig. 2. Research method

\section{RESULT AND DISCUSSION}

\section{A. Research results}

In the concept of learning there always exist the input components, processes, and results. These three components affect success in learning. Just as in this study which focused on the description of barriers to learning level of speech Javanese in Elementary School. Data collection is done by observation of teaching materials used as well as the learning process conducted by teachers and students and interviews with the teachers and students.

In result of observation of learning, some obstacles in learning are found. These constraints include: (1) many students who are less able to use the correct level of Javanese speech; (2) Javanese book used is less interesting and has only black and white images; (3) students rarely apply the conversation by using krama language with the elders (4) Students who come from out of central Java but studying in central Java are unable to use Javanese speech levels, if there are some children who apply a little degree of Javanese spoken language, then mixed code occurs; (5) in the learning of Javanese language, the dominant one is the teacher, thus, less students lack communicative skills because of the number of students and less learning time.

In the interviews conducted towards the students, it was known that that the language of Java is boring, that it is difficult to learn and that there is the notion that Javanese lessons are not too important because it is the local one and is not included in the national exams.

Exposure of interview result with teachers revealed that (1) teacher stated that $95 \%$ of the learners do not master some material in Javanese, one of them is the level of speech of Javanese language; (2) teachers of Javanese language subjects did not come from Javanese or linear language education with Javanese language so that they lack mastery of the material taught, i.e. 55\% Java language subjects are taught by principals who are not from the Javanese language education; (3) with the busyness of the principal, Javanese language subjects are not routinely taught every week so that the variety of speech levels of Java language is less understood by learners; (4) lack of using Javanese language speech in school; (5) very short time allocated for Javanese lessons; (6) teachers' role in the class are more dominant than students; (7) learning facilities such as LCD projectors are so limited that cause teachers use only grayscale handbooks so that students are often sleepy and don't pay attention to the teachers' explanations.

Thus, constraints in learning Java language lies in the problem of teachers' competence, the procurement of interesting Java language books, the use of appropriate learning models and adequate learning facilities and the absence of consistent and sustainable habituation.

\section{B. Discussion}

Students' learning outcomes in studying the different levels of Javanese have shown that their competence has not been satisfying. The problem of low mastery of the level of Javanese speech as a basic material for learning Java language is caused by internal and external factors. The obstacles in learning level of speech Javanese are many students are less able to use appropriate Javanese speech level especially variety of krama. Students only use variety of ngoko when requesting permission from the teacher, talking with a teacher in teachers' office, learning in class, speaking with teachers outside the classroom and the teacher also answers it without giving advice on how to talk to teacher appropriately.

One day the teacher teaches Javanese language to the students using ngoko language, then the teacher gives the question to the students by using ngoko language, then the students answered using ngoko language or the language of the variety of krama mixed with ngoko but the teacher didn't correct the students. Instead, the teacher gave examples of krama alus correctly. Another obstacle is that students who come from out of Central Java but studying in Central Java are not able to use the level of Javanese speech. If there are some children who slightly apply the level of Javanese speech, over code or mix code occurs, e.g. words "kita" In the Javanese language should be pronounced "kito", "supaya" In the Javanese language should be pronounced "supoyo", Student 
errors occur in letters "a" is pronounced "o" the word "kancakanca" Which should be pronounced with words "koncokonco" and "rubeda nir sambekala" Which should be pronounced with "rubedo nir sambekolo", word e be pronounced " $\varepsilon$ " For example on word kendel and kendhel, etc. This has relevance with the research from [12] about decoding basa walikan - a preliminary analysis of Malang 'reverse' language.

The learning of Javanese language has two abilities that must be mastered by the students, namely the ability of language or linguistic ability and communicative ability, but in reality, the dominant role in the class is the teacher, thus, the students lack communicative ability. This is because of the large number of students in one class and very short time allotment.

There is a factor of the students themselves that is the passion of learning Java language among primary school students are generally low, both intrinsic and extrinsic motivation (scarcity of books, the status of Java is considered less important). The result of this research is corroborated with the results of the emergence of the problem and is caused by low motivation of learning.

Teachers state that $95 \%$ of the learners do not master some material in Javanese, one of them is the level of speech of Javanese language; (2) teachers of Javanese language subjects did not come from Javanese or linear language education with Javanese language so that they lack mastery of the material taught, i.e. 55\% Java language subjects are taught by principals who are not from the Javanese language education; (3) with the busyness of the principal, Javanese language subjects are not routinely taught every week so that the variety of speech levels of Java language is less understood by learners

The absence of routine learning and lack of habituation using the level of Javanese speech in school makes the mastery of the level of Javanese language speech students low. In addition, the allocation of time for Javanese lesson is only 2 hours of lessons every week.

In this research, there are many obstacles in learning level of Javanese speech among elementary school students. Therefore, the innovation of learning Java language needs to be done because of the demanding needs of learners and the increasingly complex and diverse characteristics of learners. Many problems arise from the varied characteristics of learners who are influenced by the background of his residence so that in learning the level of Javanese speech there are many mix code and error in pronunciation. This is in line with the results of research by [13] that the error level of speech Javanese lies in the lexicon used and the use of Javanese speech level is influenced by gender, age, social status, and kinship. Then, the results of research conducted by [3] about the effect of Bahasa Indonesia as a lingua franca on the Javanese system of speech levels and their functions.

Javanese language speech learning needs to be optimized in order to preserve the rich culture of the nation that is rich in high moral values. Javanese learning can basically be used as a vehicle for moral values, character, especially through the application of Javanese speech level in Java society and has a central role in the development of character and character of the nation. Learning Javanese is expected to help learners recognize themselves, their environment, apply in their cultural manners, appreciate the potential of their nation, so as to express ideas and feelings, participate in society, and can find and use their analytical, imaginative skills with Javanese level of appropriate speech.

The importance of learning level of Javanese speech in elementary school is because of the level of Javanese speech is an ethics that reflects the normative paradigm that is realized in the act of language. This is in accordance with research from [14] about the politeness of prosody of the Javanese directive speech. In the level of speech, there are rules of speech as a symbol of manners that must be understood. In this case, manners are the duty of the Javanese to have a noble character. The importance of the level speech of Javanese is able to prevent moral decline. In addition, according to [15] learning level of Javanese speech is useful in ethical with regard to the age level of a person, among others, individual maturity, social maturity and spiritual maturity.

\section{CONCLUSION}

Javanese learning can basically be used as a vehicle for moral values, character, especially through the application of Javanese speech level in Java society and has a central role in the development of character and character of the nation. However, in its implementation, there are some obstacles so that lessons are less meaningful, passive and not applicative. In overcoming the obstacles in learning the level of Javanese speech learning innovation is required, such as with the use of appropriate learning model, the use of Javanese language spoken well, improving learning facilities and teaching materials used, improving teacher competence.

\section{REFERENCES}

[1] L. Darling-Hammond and J. Bransford, Preparing teachers for a changing world: What teachers should learn and be able to do: John Wiley \& Sons, 2007.

[2] J. W. Stigler and J. Hiebert, The teaching gap: Best ideas from the world's teachers for improving education in the classroom: Simon and Schuster, 2009.

[3] G. Poedjosoedarmo, "The effect of Bahasa Indonesia as a lingua franca on the Javanese system of speech levels and their functions," ed, 2006.

[4] N. Mulder, Individual and society in Java: A cultural analysis: Gadjah Mada University Press, 1992.

[5] S. Marmanto, Potret bahasa Jawa krama di era globalisasi: Sebelas Maret University Press, 2014.

[6] P. Naughton and H. Schildt, Java: the complete reference: Osborne/McGraw-Hill, 1996.

[7] K. Saddhono and M. Rohmadi, "A sociolinguistics study on the use of the Javanese language in the learning process in primary schools in Surakarta, Central Java, Indonesia," International Education Studies, vol. 7, p. 25, 2014.

[8] M. C. Ewing, "Motivations for first and second person subject expression and ellipsis in Javanese conversation," Journal of Pragmatics, vol. 63, pp. 48-62, 2014.

[9] J. Sukoyo and S. Suwandi, "Hubungan Antara Penguasaan Tingkat Tutur Dan Sikap Ekstrovert Dengan Keterampilan Berbicara Krama Alus Mahasiswa Program Studi Pendidikan Bahasa Dan 
Sastra Jawa Universitas Negeri Semarang," Jurnal Pendidikan Bahasa dan Sastra, vol. 1, pp. 97-107, 2013.

[10] D. R. Krathwohl, Methods of educational and social science research: An integrated approach: Longman/Addison Wesley Longman, 1993.

[11] M. B. Miles, A. M. Huberman, and J. Saldana, "Qualitative data analysis: A method sourcebook," CA, US: Sage Publications, 2014.

[12] N. Yannuar, E. Iragiliati, and E. L. Zen, "Bòsò Walikan Malang's Address Practices," GEMA Online® Journal of Language Studies, vol. 17, 2017.
[13] B. Indrayanto and K. Yuliastuti, "Fenomena Tingkat Tutur dalam Bahasa Jawa Akibat Tingkat Sosial Masyarakat," MAGISTRA, vol. 26, p. 37, 2015 .

[14] V. I. Podlesskaya, "Parameters for typological variation of placeholders," Fillers, pauses and placeholders. Typological Studies in Language, Amsterdam: John Benjamins, pp. 11-32, 2010.

[15] A. Wijayanto, "The Emergence of the Javanese Sopan and Santun (Politeness) on the Refusal Strategies Used by Javanese Learners of English," Online Submission, vol. 36, pp. 34-47, 2013. 